\title{
Increasing Teamwork, Organizational Commitment and Effectiveness through the Implementation of Collaborative Resolution
}

\author{
S. MARTONO ${ }^{1}$, Moh. KHOIRUDDIN ${ }^{2}$, Andhi WIJAYANTO³ ${ }^{3}$, Siti RIDLOAH4, \\ Nury Ariani WULANSARI ${ }^{5}$, Udin UDIN ${ }^{6}$
}

Received: March 27, 2020 Revised: April 04, 2020 Accepted: May 01, 2020

\begin{abstract}
This study seeks to examine empirically the effect of leadership style on organizational commitment and organizational effectiveness. The data are from all departments of the undergraduate program at the State University in Central Java, Indonesia. The study comprises all divisions of the undergraduate program, which amounted to 207 people. The method for sampling is based on simple random sampling. Structural equation modeling (SEM) is applied in order to analyze the data. The results show that integrative adaptive leadership style has a positive effect on teamwork and affective commitment. Therefore, in order to improve teamwork, the organization should be assisted in completing the introduction of collaborative conflict resolution. Moreover, affective commitment positively affects organizational effectiveness. Thus, it can be said that efforts to improve the organizational effectiveness, should be supported by affective commitment. The study further revealed that integrative adaptive leadership style has a positive effect on teamwork. This means better execution of integrative adaptive leadership, higher level of coordination and vice versa. Each member has different responsibilities and duties, and it can be done or resolved in different ways. If the leader can accommodate the creativity of the faculty and staff, a solid team can be formed.
\end{abstract}

Keywords : Teamwork, Organizational Commitment, Organizational Effectiveness, Indonesia.

JEL Classification Code: D21, D22, L20, L21.

\section{Introduction}

Measuring the effectiveness of an academic accreditation component is describing the institution's ability to achieve

${ }^{1}$ Firts Author. Lecturer, Economic Faculty, Universitas Negeri Semarang, Semarang, Indonesia. Email: martono@mail.unnes. ac.id

${ }^{2}$ Lecturer, Economic Faculty, Universitas Negeri Semarang,

Semarang, Indonesia

${ }^{3}$ Lecturer, Economic Faculty, Universitas Negeri Semarang,

Semarang, Indonesia

${ }^{4}$ Lecturer, Economic Faculty, Universitas Negeri Semarang,

Semarang, Indonesia

${ }^{5}$ Lecturer, Economic Faculty, Universitas Negeri Semarang,

Semarang, Indonesia

${ }^{6}$ Corresponding Author. Lecturer, Business and Economic Faculty, Universitas Muhammadiyah Yogyakarta, Indonesia [Postal Address: Jl. Brawijaya, Tamantirto, Kec. Kasihan, Yogyakarta, 55183, Indonesia] Email: udin_labuan@yahoo.com

(c) Copyright: The Author(s)

This is an Open Access article distributed under the terms of the Creative Commons Attribution Non-Commercial License (http://Creativecommons.org/licenses/by-nc/4.0/) which permits unrestricted noncommercial use, distribution, and reproduction in any medium, provided the original work is properly cited. the quality of the education system, especially with regard to university tri-dharma in Indonesia. Attaining the accreditation score " $A$ " requires the strength and commitment of all elements that exist within the study program unit. Diverse requirements for obtaining these scores should be met. Due to the limitations and availability, the demand for organizational resource management that supports the achievement of the goals is significant. In reality, however, supporting resources are rather limited. This raises some problems, including organizational conflict, commitment and job satisfaction.

Substantive conflict is a conflict with regard to judgments, instructions and acts, as well as conflicts with regard to matters of duty (Afzalur Rahim, 2002; Jehn \& Mannix, 2001), including the essence and importance of tasks and decisions, such as the method for completing the task and the selection of appropriate actions (Pelled, 1996). The substantive conflict is also called task conflict (Jehn \& Mannix, 2001) or cognitive conflict (Amason, 1996). Affective conflict relates to personal incompatibility, conflict of emotions indicated by distrust, anger, dissatisfaction, and other forms of negative 
affects (Davis \& Harveston, 2001; Jehn \& Mannix, 2001). Studies on conflicts reflect a substantive disagreement in the performance of duties.

Resource management in the university at the level of faculties, departments, and programs of study can bring substantive conflict because of differences in interests and short-term goals. Some potential resource conflicts such as substantive requirements involving faculty lecturer and other courses, the utilization of laboratory facilities for some courses, scheduling, budget and cost plans, faculty development, and management of research and community service by faculty.

Cooperation in the organization covers all aspects of the organization's resources, including human resources. The characteristic of human resources is the most critical part because it is a driver of activity in an organization. However, not all resources are available at the faculty level, departments, and study programs. These limited resource factors create motivation for the importance of cooperation, so that each unit can benefit optimally at the faculty level, departments, and study programs. The needs of resources related to other study programs, such as the needs of lecturers, generally occur in all universities on the grounds of specialization and expertise.

Conflict of duties associated with the quality of innovation and ideas (Amason, 1996), can increase constructive criticism (Jehn, Northcraft, \& Neale, 1999), and facilitate the effective use of organizational resources. However, other research suggests that substantive (task) conflict may also have negative effects on the organization (Guerra, Martínez, Munduate, \& Medina, 2005). Conflicts can make the work environment less comfortable, reduce individual perception about teamwork and job satisfaction (Jehn, 1997), increase anxiety, and have greater impact in making the employee ostracized from the group (Jehn, 1995). The result showed that there were differences of opinion on relationship conflict with team collaboration. Tjosvold, Law, and Sun (2006) showed that substantive conflict does not affect the effectiveness of teamwork. The approach to competition negatively affects the effectiveness of teamwork. Other studies related to conflict management by Aritzeta, Ayestaran, and Swailes (2005) showed that there was a negative correlation between integrative style and teamwork.

The contradicting results of other studies mention a positive relationship between conflict management style with an integrative approach and teamwork. Furumo (2009), who studied at the US university (Midwestern), found that conflict management style approach has a positive effect on the integration of teamwork. Based on the background of this study, the main issue to be examined is: how to improve the implementation of the resolution of collaborative teamwork, commitment, and organizational effectiveness. This research aims to empirically investigate the relationship between leadership style and commitment and organizational effectiveness.

\section{Literature Review and Hypotheses Development}

\subsection{Organizational Conflict}

According to Luthans and Youssef (2007), a conflict is a condition caused by the presence of opposing forces. Every employee in the workplace will find two forms of conflict: conflict related to decisions, ideas, directions, and actions called substantive conflict, and personal conflict, where both sides do not like each other (Afzalur Rahim, 2002). The substantive conflict is also called task conflict (Pelled, 1996) or cognitive conflict (Amason, 1996). The personal conflict is also called affective conflict (Amason, 1996), or relationship conflict (Guerra et al., 2005; Jehn, 1995). Affective conflict is discord and lack of consensus or approval among members of the group over personal issues unrelated to the task. A view on conflict resolution in organizations is often equated with conflict management (Slimani, Da Silva, Médini, \& Ghodous, 2006). Conflict management involves the design of macro-level strategies to minimize constructive dysfunctional conflict and functional conflict to increase organizational effectiveness (Afzalur Rahim, 2002), whereas the conflict resolution involves reduction and conflict resolution by utilizing communication to parties which involve on the conflict (Salami, 2010).

One way to resolve conflicts is to see to what extent the groups have an internal and external focus on resolution strategies used. Specifically, Thomas (2008) developed a style of conflict resolution based on two dimensions of cooperation to satisfy other people when faced with conflict, and assertiveness in order to satisfy themselves when faced with conflict. This raises two points of view and five different approaches to resolve the conflict (Thomas, 2008) the dominance approach, accommodation, collaboration, avoidance, and compromise (Ivancevich, Konopaske, \& Matteson, 2005; Luthans \& Youssef, 2007). Figure 1 illustrates a conflict resolution model.

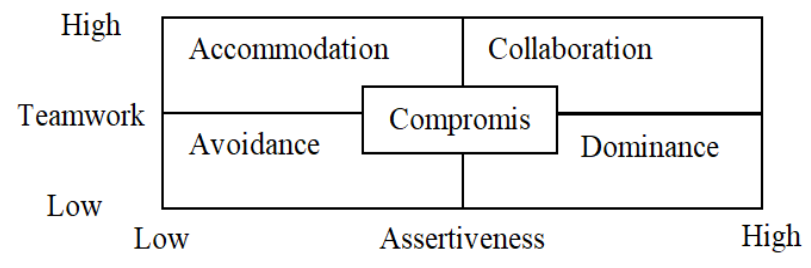

Figure 1: Conflict Resolution Model 


\subsection{Leadership}

Leadership is the process of using influence without coercion to fulfill the goal of the organization (Griffin, 2006). Some leadership models commonly found in the practice of the organization are the situational leadership model, transformational leadership model, adaptive leadership model, and integrative adaptive leadership model. Situational leadership model is the development of the character leadership model with the main focus situation variable as a determinant factor of leadership ability. The situational model does not only discuss the character of the leader, but also leadership based on its function. This model is still considered inadequate because it cannot predict leadership skills regarding the effectiveness of this model. Walumbwa and Lawler (2003) stated that transformational leadership emphasizes that a leader requires to motivate subordinates to produce an outstanding performance. According to Yukl (1999), the original formation of the theory of transformational leadership includes three main components, namely, charisma, intellectual stimulation, and individual-oriented attention.

Adaptive leadership is defined as an interactive pattern where knowledge, action preferences, and behavior change can stimulate an organization to be more adaptive (Burke, 2007; Lichtenstein et al., 2006). Adaptive leadership would not expect subordinates to follow the wishes of the leader; on the contrary, leadership occurs when the interaction patterns manifest adaptive outcomes. The approach to understanding the relationship between leaders and subordinates expresses transactional, transformational, and charismatic leadership model. Transactional leadership describes the relationship between leaders and employees as one of exchange and reward compliance. Transformational leadership tried to motivate employees to work towards our goal not only for short-term personal interests, but also for achievement and self-actualization (McLaurin \& Al Amri, 2008). Charismatic leadership type tried to make the motivation atmosphere based on commitment and emotional identity to the vision, philosophy, and style within subordinates (McLaurin \& Al Amri, 2008). The relationship between transactional and transformational leadership styles led to adaptive leadership style (Van Slyke \& Alexander, 2006).

Integrative adaptive leadership is based on the fact that no theory of leadership can adopts all aspects of the relationship between leaders, followers, and environmental organizations (Avolio, 2007). In fact, the theory of transformational leadership is still focused on leadership in relation to followers (Glover, Rainwater, Jones, \& Friedman, 2002). Integrative adaptive leadership model is not only focused on the traditional concern for the leader-follower relationship but also focusing on the relationship with the leader in a complex environment (Yuniawan, Putri, \& Udin, 2017).

\subsection{Organizational Commitment}

The high commitment of employees to the organization will support the high performance, low employee turnover, and low levels of absenteeism. The commitment will determine the level of satisfaction in the work (Lambert, Pasupuleti, Cluse-Tolar, Jennings, \& Baker, 2006). In other words, job satisfaction will be triggered if the organization could increase the commitment of its employees. Employee commitment to the organization is a continuous process, and it is an individual experience when joining an organization.

\subsection{Social Affiliate}

The desire to be socially acceptable, and to avoid social rejection is the primary human needs (Nikitin \& Freund, 2008). Views about social affiliation are at the core of the identification (Aiken \& Koch, 2009). In this interpretation, individuals gain a sense of internal identity of their relationship to the social groups. Team members often bind themselves to the perception of group affiliation (Fisher \& Wakefield, 1998). Teamwork within the organization can be regarded as a mature group that consists of people who are mutually dependent, motivated, and committed to achieving mutually agreed objectives (Valle \& Witt, 2001). A total commitment to team goals and accountability are the main factors that differentiate a team and group.

\subsection{Organizational Effectiveness}

Organizational effectiveness is measured from the level of achievement of the objectives. The effectiveness of the organization consists of individuals and groups $(\mathrm{Hu}$ \& Liden, 2011; Ng, Ang, \& Chan, 2008). However, the effectiveness of an organization is much more than the magnitude of the effectiveness of individuals and groups, so that the organization can be effective if it is able to get to a higher level of work than the amount of work of each of its parts. Cameron (1978) developed a model for assessing the effectiveness of the organization of higher education institutions in the United States. This model introduces nine dimensions of organizational effectiveness, namely: students' satisfaction, students' academic development, career development of students, personal development of students, faculty administrative employee satisfaction, quality and faculty professional development, openness and community interaction system, the ability to acquire resources, and the health of the organization. Cameron's instrument is then adopted by Kwan and Walker (2003) to examine the educational institutions in Hong Kong, with some modifications.

Table 1 shows the dimensions and indicators of organizational effectiveness that has been modified by Kwan 
and Walker (2003). This opinion is in line with the guidelines for assessing program study by the National Accreditation Board for Higher Education (BAN-PT).

\subsection{The Relationship between Collaborative Resolution and Integrative Adaptive Leadership}

The collaborative approach in which a conflict resolution can be resolved in a way that allows for a win-win solution is a reference to the parties involved in a conflict. The collaborative approach emphasizes collaboration, synchronization in differences, openness, the involvement of others in solving problems, and integration in decision making. Thus, based on a collaborative approach the role and task of the leader should be to adapt and develop a compatibility with the organization's environment. Glover et al. (2002), Lee (2018) explained that the leader always optimizes dimensional adaptive assimilation and accommodation. The adaptive leadership style is more oriented to the desires of employees following the environmental conditions. Adaptive leadership is also more creative and innovative, open, and responsible.

H1: Collaborative resolution affects integrative adaptive leadership style.

Table 1: The Dimensions of Organization Effectiveness in Educational Institution

\begin{tabular}{|c|c|c|}
\hline No & Dimension & Indicators \\
\hline 1. & Students satisfaction & $\begin{array}{l}\text { - Students enjoy campus life } \\
\text { - A good relationship between students and faculty } \\
\text { - High satisfaction of students to their study program }\end{array}$ \\
\hline 2. & $\begin{array}{l}\text { Academic } \\
\text { development of } \\
\text { students }\end{array}$ & $\begin{array}{l}\text { - Students achieve high academic performance } \\
\text { - Students just want to achieve the academic qualification, not for getting knowledge } \\
\text { - Students as autonomous students }\end{array}$ \\
\hline 3. & $\begin{array}{l}\text { Career development } \\
\text { of students }\end{array}$ & $\begin{array}{l}\text { - Alumnus get a job easily } \\
\text { - Their job appropriates with their background of the study } \\
\text { - Recommended by job giver }\end{array}$ \\
\hline 4. & $\begin{array}{l}\text { Personal } \\
\text { development of } \\
\text { students }\end{array}$ & $\begin{array}{l}\text { - Students attention to the public interest } \\
\text { - active in an extracurricular activity } \\
\text { - Respect to lecturers }\end{array}$ \\
\hline 5. & $\begin{array}{l}\text { Lecturer's } \\
\text { satisfaction }\end{array}$ & $\begin{array}{l}\text { - Lecturers feel comfortable in teaching } \\
\text { - Lecturers like to do research } \\
\text { - The university is in the highest rank at research and publication }\end{array}$ \\
\hline 6. & $\begin{array}{l}\text { Professional } \\
\text { development and the } \\
\text { quality of faculty }\end{array}$ & $\begin{array}{l}\text { - Lecturers have the best qualification than other universities in the same region. } \\
\text { - Lecturers are pushed with high appreciation in the academic environment } \\
\text { - The university supports the development of lecturers }\end{array}$ \\
\hline 7. & $\begin{array}{l}\text { System openness } \\
\text { and community } \\
\text { interaction }\end{array}$ & $\begin{array}{l}\text { - Lecturers activity in community development programs } \\
\text { - Focused on job giver needs } \\
\text { - Lecturers enjoy good reputation from the society } \\
\text { - A good relationship with industries or other educational institutions }\end{array}$ \\
\hline 8. & $\begin{array}{l}\text { The ability to get } \\
\text { resources }\end{array}$ & $\begin{array}{l}\text { - Attract the best graduation to apply } \\
\text { - Attract and keep staff with good qualification } \\
\text { - Able to play along with other universities which get research fund } \\
\text { - Able to play along with other universities to get sponsorship from industries }\end{array}$ \\
\hline
\end{tabular}

Source: Kwan and Walker (2003) 


\subsection{The Relationship between Collaborative Resolution and Teamwork}

Conflict resolution through a collaborative approach that is caused by variations in performing the tasks will improve teamwork. The collaborative approach proposed by Thomas (2008), identical to the integrative approach proposed by Rahim (1983), and the cooperative approach (Tjosvold, Dann, \& Wong, 1992), emphasizes the importance of optimizing the dimensions of the task and concern for others. Collaborative resolution can lead to better competition between members to work. High attention to duty and the employee requires the cooperation of all components. Teamwork requires the willingness of each component at the level of faculties; departments and study programs provide all the capabilities based on their competence, for the benefit of the development of the organizational (Somech, Desivilya, \& Lidogoster, 2009).

H2: Collaborative resolution affects teamwork

\subsection{The Relationship between Integrative Adaptive Leadership and Teamwork}

The role and activities of the leader will determine the quality of teamwork within the group. Cooperation between members of the organization will not run well if it is not supported by the attitude and behavior of the leader. This means that the quality of cooperation as an integral member of the organization in completing a task depends on the leadership of the organization as a driver. The adaptive integrative leader would look at a team as an essential part of achieving objectives (Nguyen, Mai, \& Huynh, 2019; Yuniawan et al., 2017). Every member has different duties and responsibilities and can be done in different ways. In the organization, the most important thing is not how the organization creates uniformity, but how the goals can be achieved with the existence of such differences. A solid team can be formed if the leader is able to accommodate the creativity of subordinates.

H3: Integrative adaptive leadership style affects teamwork

\subsection{The Relationship between Collaborative Resolution and Affective Commitment}

Conflict resolution variable with derivation in collaborative resolution is selected in this study. Substantive conflict arises when a person is carrying out a task that was not relevant to the background and personal goals (Afzalur Rahim, 2002). Substantive conflict is related to a person's tasks performed in the organization. Specifically, this research examines the collaborative resolution variable; it refers to the results of Syna Desivilya and Yagil (2005) that the resolution model, which has a positive relationship with task conflict (substantive), is an integrative approach (collaborative), with the emergence of substantive conflict to organizational commitment. Selecting this variable assuming there are no studies, which explicitly disclose the relationship between collaborative resolution and organizational commitment.

\section{H4: Collaborative resolution affects affective} commitment

\subsection{The Relationship between Integrative Adaptive Leadership and Affective Commitment}

Substantive conflict resolution process with the optimal collaborative approach will make the employee feel needed and remains willing to stay in the organization. It means that the conflict, which is related to the execution of the task will be necessary for the leaders to support their commitment as part of the organization. A high or low relationship between substantive conflicts with employee commitment to the organization is determined by the strength of the leader in resolving the substantive conflict. Some research indicates the role of the leader in relation to the commitment demonstrated significant results, such as Chih and Lin (2009) and Huynh, Do, and Truong (2019).

H5: Integrative adaptive leadership style affects affective commitment

\subsection{The Relationship between Affective Commitment and Organizational Effectiveness}

The strength of the organization in achieving its goals is largely determined by the ability and willingness of members of the organization to continue to work in all situations (Djastuti, Perdhana, \& Udin, 2019). It means that the organization's objectives will be achieved if each member is committed to continuing to work and excel in the organization. The members of the organization only think to actualize their competence in the organization and had no desire to get out or move to another organization. The consistency of the process of achieving the goal will remain intact in each unit, and ultimately the sustainability of the organization is maintained.

Substantive conflict allows competition based on the desire of employees to complete the work as well as possible. Competition between members of the group will be better if each member of the organization has a strong commitment to the organization. Employees who have a high commitment will still feel part of the organization and try to perform for the organization. Although there are substantive conflicts, 
the organizational goals can be achieved effectively. Ussahawanitchakit (2008) stated that organizational commitment has a positive effect and significant to the effectiveness of the organization. This means that a high employee commitment to the organization would increase the effectiveness of the organization.

Research by Nelson, Brunetto, Farr-Wharton, and Ramsay (2007), Udin, Handayani, Yuniawan, and Rahardja (2017), and Akbar, Udin, Wahyudi, and Djastuti (2018) explain that affective commitment affects organizational effectiveness. The results by Zhang and Liu (2010) also stated that affective commitment positively affects organizational effectiveness. This indicates that a person's commitment to remain loyal and work in a particular organization provides the power for individuals and organizations to achieve goals.

H6: Affective commitment affects organizational effectiveness

\section{Research Methods}

The study comprises all divisions of the undergraduate program at the State University in Central Java-Indonesia, amounting to 207 persons. The method for sampling is based on simple random sampling.

Measurement of collaborative resolution indicators: to understand the importance of cooperation (RK1), awareness of the difference (RK2), and efforts to create transparency (RK3). Measurement of collaborative resolution uses three-question items developed by Afzalur Rahim (2002), Ivancevich et al. (2005), and Robbins (2008).

Measurements of teamwork indicators: trying to form the best group (KT1), communicate dynamically (KT2), and routinely coordinate (KT3). Teamwork was measured using three items from questions developed by Al-Rawi (2008), Ivancevich et al. (2005), Hoegl and Gemuenden (2001).

Measurement of adaptive integrative leadership indicators: seek to understand the characteristics of members (PA1), trying to improve managerial competence (PA2) and efforts to create synergy (PA3). Integrative adaptive leadership variable was measured using three-item questions developed by Glover et al. (2002), Hogan (2008), Lichtenstein et al. (2006), Burke (2007), and Avolio (2007).

Measurement of affective commitment indicators: trying to be loyal to the department (KA1), proud of the department (KA2), trying to become part of the department/ study program (KA3), and has a suitability value (KA4). Measurement of affective commitment variable uses the four-item questions from Allen and Meyer (1993), Al-Rawi (2008), and Mayhew, Ashkanasy, Bramble, and Gardner (2007).
The indicators of the effectiveness of the organization include: increase the quality of study programs (EO1), academic achievement (EO2), and the quality of learning (EO3). Measurement of organizational effectiveness uses three-item questions developed by Cameron (1978), Kwan and Walker (2003), and combined with models of BAN-PT accreditation assessment. Each item was measured using seven questions measuring scale, where 1 (one) indicates "strongly disagree," and 7 (seven) indicates "strongly agree."

\section{Results and Discussion}

\subsection{Data Normality Evaluation}

The inference provided in the causality test is that research data should normally be distributed, which is confirmed by both univariate and multivariate proof. Testing normality of the data is done by using a critical ratio with a comparison figure $\mathrm{z}$ (Hair et al., 2017). The result shows that each indicator and multivariate for 0.530 is fewer than 2.58. Thus, it can be said that the data used in this study are normally distributed.

\subsection{Evaluation of Multicollinearity}

A result of the analysis of the covariance matrix determinant of the sample in this study was 4.767 . Therefore the test results reveal that the determinant's value is very high, and it can be said that there is no multicollinearity.

\subsection{Full Model of SEM (Structure Equation Modeling)}

The results of processing the full SEM can be seen in Figure 2, Table 2, and Table 3. The test results in Figure 2 show that the model is according to the data in this study. This is indicated by the Chi-square value, probability, CMIN/DF, GFI, TLI, and RMSEA, AGFI are in the expected range of values. Data from Table 2 are used as the basis for calculating the SEM. It appears that the model is acceptable.

From Table 3, it can be seen that each variable relationship has a significant coefficient standardized estimate with the Critical Ratio (CR) value. The results of the calculation between collaborative resolution and integrative adaptive leadership shows the value of the parameter beta $(\beta)=0.588$, standard error of the parameter estimate $\operatorname{SE}(\beta)=0.103$, the value of $C R=5.695$, the error rate probability value $p=$ 0.000 with a significance level of $5 \%$. Thus, Hypothesis 1 is accepted. This indicates that integrative adaptive leadership is influenced by collaborative resolution. The results of this analysis have supported the fact that the understanding of the importance of cooperation and continuously strive to create transparency that is based on the difference 


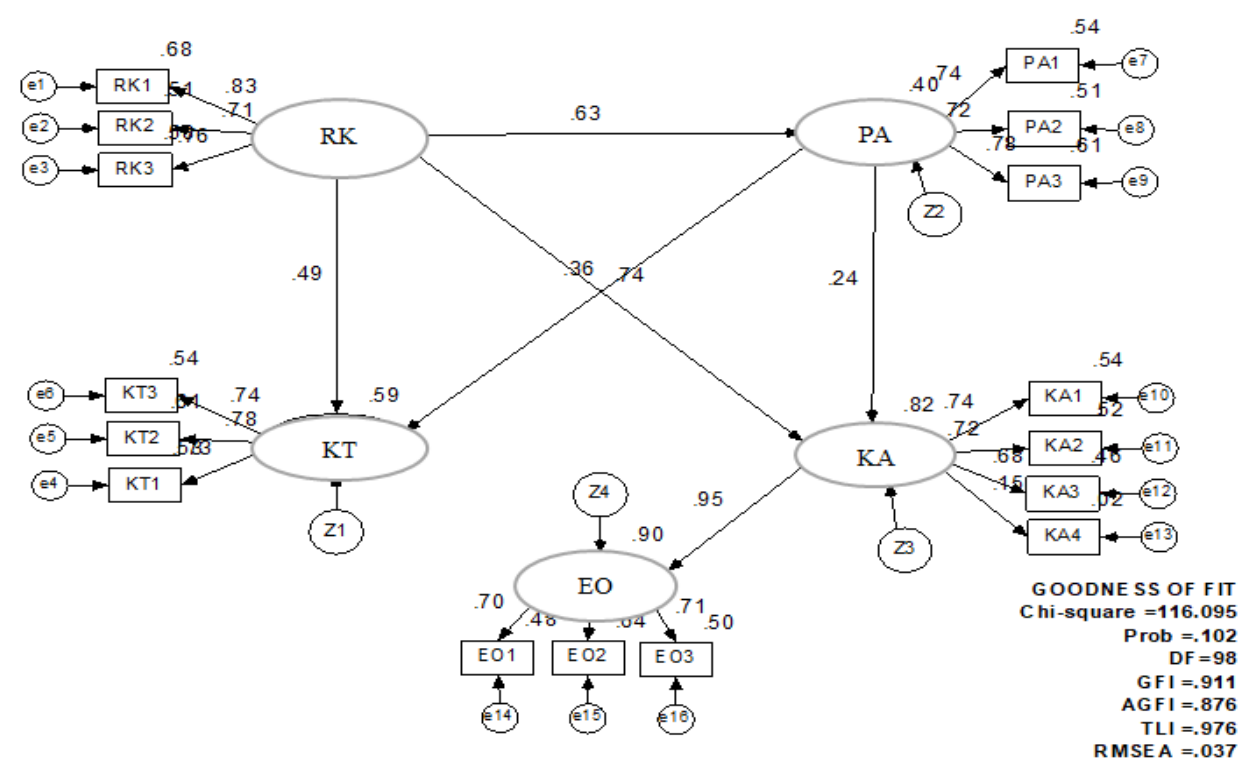

Figure 2: Full Model of Structural Equation Modeling

Table 2: Feasibility Testing Index SEM

\begin{tabular}{|l|c|c|c|}
\hline \multicolumn{1}{|c|}{ Goodness-of-fit index } & Cut off-value & Result & Explanation \\
\hline Chi-square & 119.871 & 116.095 & Good \\
\hline Probability & $\geq 0.05$ & 0.102 & Good \\
\hline RMSEA & $\leq 0.08$ & 0.037 & Good \\
\hline GFI & $\geq 0.90$ and close on 1 & 0.911 & Good \\
\hline AGFI & $\geq 0.90$ and close on 1 & 0.876 & Good \\
\hline CMIN/DF & $\leq 2.00$ & 1.185 & Good \\
\hline TLI & $\geq 0.90$ and close on 1 & 0.976 & Good \\
\hline CFI & $\geq 0.90$ and close on 1 & 0.981 & \\
\hline
\end{tabular}

Table 3: Regression Weights

\begin{tabular}{|l|c|c|c|c|c|c|}
\hline & & & Estimate & S.E. & C.R. & P \\
\hline Integrative & $<---$ & Collaborative & 0.588 & 0.103 & 5.695 & ${ }^{* * *}$ \\
\hline Commitment & $<---$ & Collaborative & 0.653 & 0.113 & 5.785 & ${ }^{* * *}$ \\
\hline Commitment & $<---$ & Integrative & 0.228 & 0.098 & 2.315 & 0.021 \\
\hline Teamwork & $<---$ & Collaborative & 0.397 & 0.104 & 3.832 & ${ }^{* * *}$ \\
\hline Teamwork & $<---$ & Integrative & 0.315 & 0.112 & 2.813 & 0.005 \\
\hline Effectiveness & $<---$ & Commitment & 0.791 & 0.114 & 6.927 & ${ }^{* * *}$ \\
\hline
\end{tabular}

reflected the support of administrative staff, as well as the implementation of activities that have been carried out in a transparent and accountable. Awareness of the importance of collaboration requires leadership to be able to understand the characteristics of its members.

Estimation parameter of the collaborative resolution and teamwork demonstrated the value of the parameter beta $(\beta)=0.397$, standard error of the parameter estimate SE $(\beta)=0.104$, the value of $\mathrm{CR}=3.832$, the error rate probability value $p=0.000$ with a significance level of $5 \%$. Thus, Hypothesis 2 is accepted. These results indicate that teamwork is influenced by collaborative resolution. Thus, it can be seen that efforts to improve team collaboration should be supported by collaborative resolution models in resolving 
conflicts at the level of departments. An understanding of the importance of teamwork as one of the reliable indicators in collaborative resolution will empirically determine how effective communication can be built to get support from each member (Tjosvold et al., 1992). Furthermore, Slimani et al. (2006) explained that an excellent problem-solving effort requires the willingness of both groups to work together to seek a unified settlement that can satisfy both groups. This means that every member of the organization must understand the importance of collaboration within an organization.

Estimation parameter between integrative adaptive leadership and teamwork demonstrated the value of the parameter beta $(\beta)=0.315$, standard error of the parameter estimate $\operatorname{SE}(\beta)=0.112$, the value of $\mathrm{CR}=2.813$, the error rate probability value $\mathrm{p}=0.005$ with a significance level of 5\%. Thus, Hypothesis 3 is accepted. These results indicate that teamwork is influenced by integrative adaptive leadership. The results of the study indicate that, in efforts to improve teamwork should be supported by integrative adaptive leadership style. Support for the acceptance of the hypothesis can be empirically observed from open answers of the respondents that the perception of a leader in understanding the characteristics of members on aspects of individual and group behavior, and habits that are supported by the spirit of togetherness can establish a dynamic communication verbally, formal and informal, as well as the mutual support in the form of an idea, and the totality of devotion in the form of responsible teamwork.

The results of the calculation of estimated parameters between the collaborative resolution and affective commitment indicates the value of the parameter beta $(\beta)=0.653$, standard error of the parameter estimate SE $(\beta)=0.113$, the value of $\mathrm{CR}=5.785$, the error rate probability value $\mathrm{p}=0.000$ with a significance level of 5\%. Thus, Hypothesis 4 is accepted. These results indicate that affective commitment is influenced by collaborative resolution variables. The results of this analysis support previous studies (Karadal, Ay, \& Cuhadar, 2008; Lambert et al., 2006) that substantive or task conflict has a positive effect on organizational commitment. Specifically explained is that collaborative resolution puts greater emphasis on the importance of teamwork, and effort to create transparency would be able to make people remain loyal (Jehn, 1997) and try to have a relationship with the department/study program. Basic understanding of the importance of teamwork is a strong reason for a person to work as well as possible.

Based on the answer description of the respondents about collaborative resolution that covers five aspects and consistent with open answer that every member of study program/departments have an obligation to solve the problem, and should take the time to activities of departments, but sometimes in response to the activities of department is not cohesive because it happens without deliberation. Furthermore, affective commitment, which is created from six indicators, in accordance with the descriptive analysis of the respondents' answers, indicate an average criteria, and the results were consistent with the results of the analysis that: there is still a perception of loyalty caused by working life factor; there is still a need to improve the work ethic in order to provide something better; and there is the notion that the study program is not able to give the best so that some lecturers are involved in activities outside study program.

The results of the calculation of estimated parameters between integrative adaptive leadership and affective commitment indicate the value of the parameter beta $(\beta)$ at $=0.228$, standard error of estimate parameters $\operatorname{SE}(\beta)=$ 0.098 , the value of $\mathrm{CR}=2.315$, the error rate probability value $p=0.021$ with a significance level of $5 \%$. Thus, Hypothesis 5 is accepted. These results indicate that affective commitment is influenced by integrative adaptive leadership. This result can be empirically explained that the efforts of the leader to understand the characteristics of the members can push a person to be loyal to the department/ study program. Understanding of the members is not only emphasized to respect other people's opinion because of their age or experience, but also using affective understanding to understand the characteristics of people.

The result of the calculation of estimated parameters between affective commitment and organizational effectiveness shows the value of the parameter beta $(\beta)=$ 0.791 standard error of the parameter estimate $\mathrm{SE}(\beta)=0.114$, the value of $\mathrm{CR}=6.927$, the error rate probability value $\mathrm{p}=$ 0.000 with a significance level of $5 \%$. Thus, Hypothesis 6 is accepted. These results indicate that the effectiveness of an organization is influenced by affective commitment. Feeling proud to be part of the department/study program can increase the sense of belonging, defending, and maintaining the department/study program. Furthermore, it may increase academic quality, especially in the learning aspect. The desire to improve the quality of the department/study program as a form of commitment and loyalty can encourage lecturers to perform optimally. Excellent performance of lecturers, especially in the field of research, can improve research publications.

\section{Conclusion}

The study results showed that the collaborative resolution to integrative adaptive leadership had a positive influence. It can be concluded that the better the implementation of the collaborative resolution, the better the integrative adaptive style of leadership. In addition, the analysis revealed a positive effect on collaborative teamwork resolution. Therefore, in order to improve teamwork, the company should be assisted in completing the introduction of collaborative conflict 
resolution at the study program level. Conflict resolution through a collaborative approach will improve teamwork due to variations in the tasks performed. Collaborative resolution can lead to a better working relationship between the members. The findings have showed that collaborative resolution has a positive effect on affective commitment. This means that the more the collaborative resolution is applied, the more the affective commitment will be improved, and vice versa.

The study outcome revealed that integrative adaptive leadership style has a positive impact on teamwork. That means the better the execution of integrative adaptive leadership, the higher the level of coordination, and vice versa. Each member has different responsibilities and duties, and it can be done or resolved in different ways. If the leader can accommodate the creativity of the faculty and staff, a solid team can be formed. However, based on the study, it has been shown that the integrative adaptive leadership style has a positive effect on affective commitment. This result shows that affective commitment is influenced by integrative adaptive leadership. This result can be explained empirically that leaders' efforts to understand the members ' characteristics can push a person to be loyal to the department/study program. Members' understanding is emphasized not only to respect the opinions of others because of their age or experience, but also to use affective understanding to understand people's characteristics. Furthermore, the result also showed that affective commitment has a positive influence on organizational effectiveness. This means that the higher the level of affective commitment, the better the level of organizational effectiveness achieved. Thus, it can be said that affective commitment should be supported in order to improve the organizational effectiveness.

\section{References}

Afzalur Rahim, M. (2002). Toward a theory of managing organizational conflict. International Journal of conflict management, 13(3), 206-235.

Aiken, K. D., \& Koch, E. C. (2009). A conjoint approach investigating factors in initial team preference formation. Sport Marketing Quarterly, 18(2), 81-91.

Akbar, A. B., Udin, Wahyudi, S., \& Djastuti, I. (2018). Spiritual Leadership and Employee Performance: Mediating Role of Organizational Commitment in Indonesian Public University. Journal of Engineering and Applied Sciences, 13(12), 43444352.

Al-Rawi, K. (2008). Cohesiveness within teamwork: the relationship to performance effectiveness-case study. Education, Business and Society: Contemporary Middle Eastern Issues, 1(2), 92106.
Allen, N. J., \& Meyer, J. P. (1993). Organizational commitment: evidence of career stage effects? Journal of business research, 26(1), 49-61.

Amason, A. C. (1996). Distinguishing the effects of functional and dysfunctional conflict on strategic decision making: Resolving a paradox for top management teams. Academy of management journal, 39(1), 123-148.

Aritzeta, A., Ayestaran, S., \& Swailes, S. (2005). Team role preference and conflict management styles. International Journal of conflict management, 16(2), 157-182.

Avolio, B. J. (2007). Promoting more integrative strategies for leadership theory-building. American psychologist, 62(1), 2533. https://doi.org/10.1037/0003-066X.62.1.25.

Burke, B. F. (2007). Adaptive leadership as a facilitator of public engagement on environmental sustainability issues. Administrative Theory \& Praxis, 29(3), 412-431.

Cameron, K. S. (1978). Measuring organizational effectiveness in institutions of higher education. Administrative Science Quarterly, 23(4), 604-632.

Chih, W.-H., \& Lin, Y.-A. (2009). The study of the antecedent factors of organisational commitment for high-tech industries in Taiwan. Total Quality Management, 20(8), 799-815.

Davis, P. S., \& Harveston, P. D. (2001). The phenomenon of substantive conflict in the family firm: a cross-generational study. Journal of small business management, 39(1), 14-30.

Djastuti, I., Perdhana, M. S., \& Udin, U. (2019). Fun at Work and Employee Performance: The Roles of Job Satisfaction and Organizational Commitment in Manufacturing Companies. Wseas transactions on business and economics, 16, 153-162.

Fisher, R. J., \& Wakefield, K. (1998). Factors leading to group identification: A field study of winners and losers. Psychology \& Marketing, 15(1), 23-40.

Furumo, K. (2009). The impact of conflict and conflict management style on deadbeats and deserters in virtual teams. Journal of Computer Information Systems, 49(4), 66-73.

Glover, J., Rainwater, K., Jones, G., \& Friedman, H. (2002). Adaptive leadership (part two): Four principles for being adaptive. Organization Development Journal, 20(4), 18-38.

Griffin, R. W. (2006). Student achievement series: Principles of management. Boston: Cengage Learning.

Guerra, J. M., Martínez, I., Munduate, L., \& Medina, F. J. (2005). A contingency perspective on the study of the consequences of conflict types: The role of organizational culture. European Journal of Work and Organizational Psychology, 14(2), 157176.

Hair, J. F., Sarstedt, M., Ringle, C. M., \& Gudergan, S. P. (2017). Advanced issues in partial least squares structural equation modeling. Thousand Oaks, CA: SAGE Publication Inc.

Hoegl, M., \& Gemuenden, H. G. (2001). Teamwork quality and the success of innovative projects: A theoretical concept and empirical evidence. Organization science, 12(4), 435-449. 
Hogan, T. J. (2008). The adaptive leadership maturity model. Organization Development Journal, 26(1), 55-61.

$\mathrm{Hu}$, J., \& Liden, R. C. (2011). Antecedents of team potency and team effectiveness: An examination of goal and process clarity and servant leadership. Journal of Applied psychology, 96(4), 851-862. https://doi.org/10.1037/a0022465

Huynh, T. T. S., Do, D. T., \& Truong, T. X. D. (2019). The Impact of Leadership Styles on the Engagement of Cadres, Lecturers and Staff at Public Universities-Evidence from Vietnam. Journal of Asian Finance, Economics and Business, 6(1), 273-280. http:// doi.org/10.13106/jafeb.2019.vol6.no1.273

Ivancevich, J. M., Konopaske, R., \& Matteson, M. T. (2005). Organizational Behavior. New York: McGraw Hill Companies.

Jehn, K. A. (1995). A multimethod examination of the benefits and detriments of intragroup conflict. Administrative science quarterly, 40(2), 256-282.

Jehn, K. A. (1997). A qualitative analysis of conflict types and dimensions in organizational groups. Administrative science quarterly, 42(3), 530-557.

Jehn, K. A., \& Mannix, E. A. (2001). The dynamic nature of conflict: A longitudinal study of intragroup conflict and group performance. Academy of management journal, 44(2), 238251.

Jehn, K. A., Northcraft, G. B., \& Neale, M. A. (1999). Why differences make a difference: A field study of diversity, conflict and performance in workgroups. Administrative science quarterly, 44(4), 741-763.

Karadal, H., Ay, U., \& Cuhadar, M. T. (2008). The effect of role conflict and role ambiguity on job satisfaction and organizational commitment: A study in the public and private sectors. The Journal of American Academy of Business, 13(2), $1-15$.

Kwan, P., \& Walker, A. (2003). Positing organizational effectiveness as a second-order construct in Hong Kong higher education institutions. Research in Higher Education, 44(6), 705-726.

Lambert, E. G., Pasupuleti, S., Cluse-Tolar, T., Jennings, M., \& Baker, D. (2006). The impact of work-family conflict on social work and human service worker job satisfaction and organizational commitment: An exploratory study. Administration in Social Work, 30(3), 55-74.

Lee, J. Y. (2018). The Effects of Job Characteristics on the Team Creativity of Distribution Companies: Moderating Effects of Transformational Leadership. Journal of Asian Finance, Economics and Business, 5(4), 161-172. http://doi. org/10.13106/jafeb.2018.vol5.no4.161

Lichtenstein, B. B., Uhl-Bien, M., Marion, R., Seers, A., Orton, J. D., \& Schreiber, C. (2006). Complexity leadership theory: An interactive perspective on leading in complex adaptive systems. Emergence: Complexity and Organization, 8(4), $2-12$.

Luthans, F., \& Youssef, C. M. (2007). Emerging positive organizational behavior. Journal of management, 33(3), 321349.
Mayhew, M. G., Ashkanasy, N. M., Bramble, T., \& Gardner, J. (2007). A study of the antecedents and consequences of psychological ownership in organizational settings. The Journal of social psychology, 147(5), 477-500.

McLaurin, J. R., \& Al Amri, M. B. (2008). Developing an understanding of charismatic and transformational leadership. Proceedings of the Allied Academies International Conference. Academy of Organizational Culture, Communications and Conflict (pp. 15). Jordan Whitney Enterprises, Inc.

Nelson, S., Brunetto, Y., Farr-Wharton, R., \& Ramsay, S. (2007). Organisational effectiveness of Australian fast growing small to medium-sized enterprises (SMEs). Management Decision, 45(7), 1143-1162.

Ng, K.-Y., Ang, S., \& Chan, K.-Y. (2008). Personality and leader effectiveness: A moderated mediation model of leadership selfefficacy, job demands, and job autonomy. Journal of Applied psychology, 93(4), 733-743. https://doi.org/10.1037/00219010.93.4.733.

Nguyen, H. M., Mai, L. T., \& Huynh, T. L. (2019). The Role of Transformational Leadership toward Work Performance through Intrinsic Motivation: A Study in the Pharmaceutical Field in Vietnam. Journal of Asian Finance, Economics and Business, 6(4), 201-212. https://doi.org/10.13106/jafeb.2019.vol6.no4.201

Nikitin, J., \& Freund, A. M. (2008). The role of social approach and avoidance motives for subjective well-being and the successful transition to adulthood. Applied Psychology, 57, 90-111. https:// doi.org/10.1111/j.1464-0597.2008.00356.x.

Pelled, L. H. (1996). Demographic diversity, conflict, and work group outcomes: An intervening process theory. Organization science, 7(6), 615-631.

Rahim, M. A. (1983). A measure of styles of handling interpersonal conflict. Academy of management journal, 26(2), 368-376.

Robbins, S. P. (2008). Organizational Behavior: Concepts, Controversies and Applications. Jakarta: PT. Prenhallindo.

Salami, S. O. (2010). Emotional intelligence, self-efficacy, psychological well-being and students attitudes: Implications for quality education. European Journal of Educational Studies, 2(3), 247-257.

Slimani, K., Da Silva, C. F., Médini, L., \& Ghodous, P. (2006). Conflict mitigation in collaborative design. International Journal of Production Research, 44(09), 1681-1702.

Somech, A., Desivilya, H. S., \& Lidogoster, H. (2009). Team conflict management and team effectiveness: The effects of task interdependence and team identification. Journal of Organizational Behavior: The International Journal of Industrial, Occupational and Organizational Psychology and Behavior, 30(3), 359-378.

Syna Desivilya, H., \& Yagil, D. (2005). The role of emotions in conflict management: The case of work teams. International Journal of conflict management, 16(1), 55-69.

Thomas, K. W. (2008). Thomas-Kilmann Conflict Mode. TKI Profile and Interpretive Report, 1-11. CPP, Incorporated. 
Tjosvold, D., Dann, V., \& Wong, C. (1992). Managing conflict between departments to serve customers. Human Relations, 45(10), 1035-1054.

Tjosvold, D., Law, K. S., \& Sun, H. (2006). Effectiveness of Chinese teams: The role of conflict types and conflict management approaches. Management and Organization Review, 2(2), 231252.

Udin, Handayani, S., Yuniawan, A., \& Rahardja, E. (2017). Antecedents and Consequences of Affective Commitment among Indonesian Engineers Working in Automobile Sector: An Investigation of Affecting Variables for Improvement in Engineers Role. International Journal of Civil Engineering and Technology, 8(10), 70-79.

Ussahawanitchakit, P. (2008). Organizational Learning Capability, Organizational Commitment, And Organizational Effectiveness: An Empirical Study of Thai Accounting Firms. Journal of International Business Strategy, 8(3), 1-12.

Valle, M., \& Witt, L. (2001). The moderating effect of teamwork perceptions on the organizational politics-job satisfaction relationship. The Journal of social psychology, 141(3), 379-388.
Van Slyke, D. M., \& Alexander, R. W. (2006). Public service leadership: Opportunities for clarity and coherence. The American Review of Public Administration, 36(4), 362374.

Walumbwa, F. O., \& Lawler, J. J. (2003). Building effective organizations: Transformational leadership, collectivist orientation, work-related attitudes and withdrawal behaviours in three emerging economies. International journal of human resource management, 14(7), 1083-1101.

Yukl, G. (1999). An evaluation of conceptual weaknesses in transformational and charismatic leadership theories. The leadership quarterly, 10(2), 285-305.

Yuniawan, A., Putri, V. W., \& Udin. (2017). Developing an alternative model for the relationship among social capital, adaptive-integrative leadership, competitive advantage, and organizational effectiveness. International Journal Of Civil Engineering And Technology, 8(11), 52-60.

Zhang, J., \& Liu, Y. (2010). Organizational climate and its effects on organizational variables: An empirical study. International Journal of Psychological Studies, 2(2), 189-201. 